\title{
«Slipp fangene fri!» - om makt og frigjøring i Minecraft: Education Edition
}

\author{
Magnus Henrik Sandberg \\ NTNU, Norges teknisk-naturvitenskapelige universitet
}

\section{Sammendrag}

Minecraft er et åpen verden-spill hvor spilleren har stor frihet til selv å velge sine aktiviteter og bestemme spillets mål. De kreative mulighetene i spillet har gjort at lærere over hele verden har tatt det i bruk i undervisning. En skoleversjon av spillet har også blitt utviklet, der læreren har mulighet til å planlegge, styre og overvåke elevaktiviteten. Det overordnede målet med denne studien er å forstå bedre hvordan spillerens frihet endres når spillet går fra å være et mål i seg selv til å bli et verktøy for læring. I denne artikkelen ser jeg på fem ulike spillelementer som bare finnes i skoleversjonen av Minecraft, og som er laget for å hjelpe læreren til å kontrollere og styre elevaktivitet i spillet. Med utgangspunkt i Foucaults begrep maktens mikrofysikk, analyserer jeg hvordan de fem spillelementene er foreslått brukt i en hjelpetekst fra utvikleren og hvordan de faktisk blir brukt i tre undervisningsopplegg. Endelig forsøker jeg, å beskrive hvilke subjektsposisjoner som spillet og undervisningsoppleggene tilbyr lærere som bruker spillet i klasserommet.

\section{Nøkkelord: Spillbasert lering; virtuell verden; Minecraft: Education Edition; diskurs- analyse; makt}

\begin{abstract}
Minecraft is an open world game where the player has a great deal of freedom to choose their own activities and determine the goals of the game. The creative possibilities of the game have made teachers all over the world use it in their classrooms. A school edition of the game has also been lauched where the teacher has the opportunity to plan, manage and monitor student activity. The overall goal of this study is to understand better how the player's freedom changes when the game goes from being as a means on its own to becoming a learning tool. In this article, I look at five different game features that are unique for the educational version of Minecraft. These are designed to help the teacher surveil and control student activity in the game. Based on Foucault's concept of the microphysics of power, I investigate how the five game elements are described in a manual and how they are actually used in three lesson plans. Finally, I try to describe which subject positions the game and the lesson plans offer teachers who use the game in classrooms.
\end{abstract}

Keywords: Gamebased learning; virtual world; Minecraft: Education Edition; discourse analysis; power

Recieved: August, 2018; Accepted: June, 2019; Published: September, 2019

Korrespondanse: Magnus Henrik Sandberg, epost: mhsandberg@gmail.com

(C) 2019 M. H. Sandberg. This is an Open Access article distributed under the terms of the Creative Commons Attribution 4.0 International License (https://creativecommons.org/licenses/by-nc/4.0/), allowing third parties to copy and redistribute the material in any medium or format and to remix, transform, and build upon the material for any purpose, even commercially, provided the original work is properly cited and states its license.

Citation: M. H. Sandberg. "'Slipp fangene fri!" - om makt og frigjøring i Minecraft: Education Edition". Fournal for Research in Arts and Sports Education, Special Issue: "Community Arts/Arts Education»Vol. 3(1), 2019, pp. 23-42. http://dx.doi. 23 


\section{H. Sandberg}

\section{Introduksjon}

Minecraft er et spill som gir spilleren stor frihet til å velge hvor hun skal gå og hva hun skal gjøre. Derfor kan det framstå som et paradoks at det virker så forlokkende på lærere, som opererer i en skolehverdag styrt av definerte mål og vurderinger. Det kan synes uunngåelig at i forsøket på å få skolen til å bli mer lik Minecraft, vil man også gjøre Minecraft mer lik skolen.

Dette siste har skjedd i helt konkret forstand, ved at det har blitt utviklet en skoleversjon av spillet. Minecraft: Education Edition, lansert i 2016, gjør det enkelt for læreren å planlegge faglig aktivitet i spillet, gir læreren ulike styringsverktøy underveis i spillet og legger til rette for at elevene kan dokumentere faglig arbeid de gjør i spillverdenen. Lærere som bruker Minecraft: Education Edition inviteres også av spillutvikleren til å delta i et sosialt felleskap på en nettportal (https://education. minecraft.net/), hvor de blant annet oppfordres til å dele sine undervisningsopplegg og forberedte læringsverdener med hverandre.

I denne studien ser jeg på hva som skjer når Minecraft: Education Edition blir brukt som verktøy for læring i skolen. Med utgangpunkt i Michel Foucaults forståelse av makt og subjektivering (Eliassen, 2016; Foucault, 1977) og supplert og operasjonalisert med nyere diskursanalytisk teori, forsøker jeg å forstå hvilke subjektsposisjoner Minecraft: Education Edition tilbyr lærere når spillet brukes i undervisning.

Begrepet subjektsposisjoner brukes her i diskursanalytisk forstand, om mulige posisjoner en aktør kan innta gjennom å identifisere seg, eller bli identifisert, med bestemte tanker og holdninger. Subjektsposisjoner er mer dynamiske og mindre formaliserte enn «roller». De foreskriver ikke hva noen skal tenke, si eller gjøre, men indikerer posisjoner de kan gjøre det fra. I denne sammenhengen synliggjør de hvordan bestemte designvalg, først i spillet og deretter i undervisningsoppleggene disse bidrar til å utforme subjektsposisjoner for lærere som bruker de med elever.

I artikkelen stilles følgende følgende forskningsspørsmål:

- Hvordan bidrar beskrivelsene av læringsfunksjonalitet i Minecraft: Education Edition til å etablere subjektsposisjoner for lærerne som bruker spillet i undervisning?

- Hvordan endrer lærerens subjektsposisjoner seg som følge av måten tre undervisningsopplegg tar disse funksjonene i bruk på?

Det er først og fremst lærere og læringsforskere jeg har ønsket å henvende meg til med dette arbeidet. Det er en utbredt misforståelse at læreren risikerer å bli overflødig når læringsspill blir tatt i bruk som ressurs i skolen. Mye forskning tyder på det motsatte, nemlig at lærerens rolle er sentral for å få et vellykket læringsutbytte av spillbasert læring (Squire \& Barab, 2004; Egenfeldt-Nielsen, Smith \& Tosca, 2008; Silseth, 2012; de Sousa, Rasmussen \& Pierroux, 2018). Det har betydning for denne analysen på to måter: En konsekvens blir at jeg må se på «spillet» som mer enn programvaren. Det er vesentlig hvordan undervisning med spillet planlegges og gjennomføres. For det 
andre understreker det betydningen av å forstå hvilke subjektsposisjoner som tilbys lærere ved bruk av spillet $\mathrm{i}$ undervisning.

\section{Minecraft}

Minecraft er et åpen verden-spill, som kom i sin tidligste utgave i mai 2009. «Open world» vil si at spilleren beveger seg fritt i spillets digitale rom. Selve Minecraft-verdenen ser forskjellig ut hver gang et nytt spill starter og er praktisk talt uendelig stor, da nytt landskap genereres automatisk rundt spilleren når hun flytter på seg. Minecraft presenterer ikke spilleren for noen spesifikk handling og hadde opprinnelig ikke noe gitt mål. I senere oppdateringer har en slags narrativ framdrift blitt innført i form av «achievements» spilleren kan jobbe for å oppnå, og en drage hun kan drepe for å fullføre spillet. Spillet selv gir imidlertid spilleren få insentiver til å forfølge et slikt prosjekt, og de fleste spillere lager heller egne mer eller mindre eksplisitte mål for sin spilling. For de fleste spillere er Minecraft altså et spill hvor man selv hensettes i en verden og selv skaper mening $i$ den.

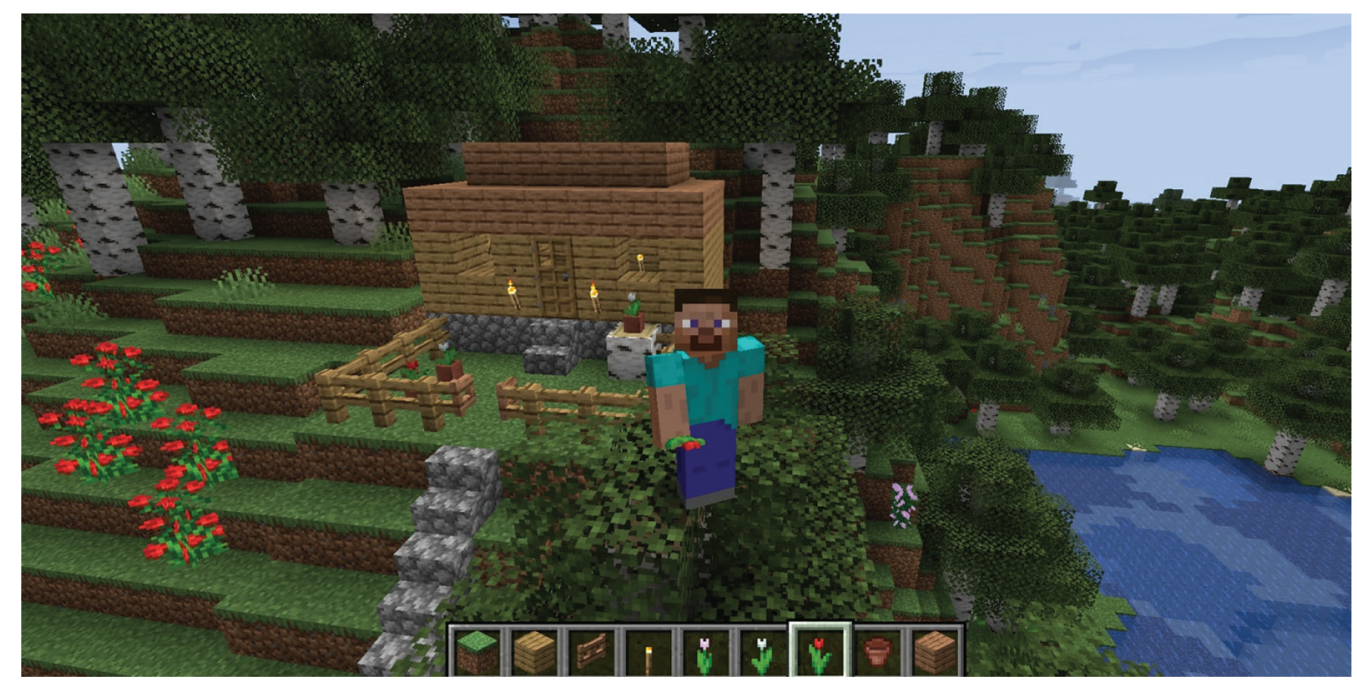

Illustrasjon 1. Skjermdump fra en av forfatterens Minecraft-verdener.

Den som spiller Minecraft har stor frihet til å selv velge hva spillet skal handle om og hvordan det skal spilles. Spilleren kan for eksempel nedlegge tid og arbeid i å plante trær og drive jordbruk, grave gruveganger i fjell, sloss mot monstre, gå ut på oppdagelsesferd eller bygge et hus på havets bunn. Friheten omfatter også metavalg som giøres utenfor spillet. Ved å velge ulike "spillmodi» kan spilleren radikalt endre spillets vanskelighetsgrad, fra "hardcore-modus» hvor hele verden og alt som er skapt i den slettes når spillkarakteren dør, til «kreativ modus» der alle farer er nøytralisert og spillet faktisk ikke lenger er et spill, men en sandkasse for kreativ bygging. Et annet 


\section{H. Sandberg}

sentralt metavalg, er spillerens frihet til å velge om hun vil spille alene eller sammen med andre. Mange velger å spille med andre på servere, der typiske aktiviteter kan være å krige mot hverandre, lage «overlevelsesutfordringer» til hverandre eller samarbeide om store byggeprosjekter. Endelig omfatter friheten spillaktivitet utenfor selve spillet. Spillere møtes på nett på ulike digitale møteplasser, av Gee kalt affinity spaces (Gee, 2006), hvor de blant annet lager og tester modifikasjoner av spillet. Minecraft-spilleren har altså frihet på flere plan, og utstrakt makt til selv å definere hvordan hun vil spille Minecraft. Johnson (2012) har argumentert for at spillmekanikk bør være den viktigste faktoren $\mathrm{i}$ å bestemme hva et spill dypest sett handler om. Med begrunnelse i friheten og de kreative mulighetene mekanikken i Minecraft gir, vil jeg hevde at spillets grunnleggende tema er frihet og kreativitet.

Når Minecraft blir tatt i bruk i skolen, skjer det imidlertid med en annen form for mål og mening. Spillet må i en eller annen forstand støtte læring, ofte med definerte læringsmål og en form for vurdering underveis eller etterpå. Spillerens frihet og egen meningsskaping må i større eller mindre grad bli erstattet av mer formelle læringsmål. Å legge opp til undervisning med et dataspill som i utgangspunktet ikke er laget for læring, stiller også store krav til lærerens didaktiske evner og forståelse. Læreren må bli en mediator mellom spillet som underholdningsprodukt og læringssammenhengen det skal inngå i (Silseth, 2012; de Sousa et.al, 2018). Det samme gjelder spill som er laget eller, som i tilfellet Minecraft: Education Edition, preparert for skolebruk (Hontvedt, Sandberg \& Silseth, 2013).

Den nye meningsskapingen som må skje når spillet tas i bruk som et verktøy for læring, tilfaller altså i større eller mindre grad læreren. Det er her jeg identifiserer en mulig maktforskyving som skjer når ikke spilleren selv får definere sitt prosjekt.

\section{Min forskerposisjon}

Min interesse for spillbasert læring med Minecraft har bakgrunn i min egen erfaring med spillet både som underholdningsspill og læringsspill. Før jeg begynte å ta spillet inn i klasserommet spilte jeg det for egen fornøyelse. Som lærer i videregående skole brukte jeg Minecraft i undervisning en rekke ganger over flere år, med ulike klasser og i ulike fag. Mine første forsøk på å bruke Minecraft i skolen, gjorde jeg med Minecraft Classic, en tidlig og enkel versjon av spillet som var gratis å spille på nett fram til 2015 (Minecraft Wiki, 2018). Senere brukte jeg den ordinære versjonen av Minecraft, etter hvert også med en læringsmodifikasjon som er en forløper til Minecraft: Education Edition, kalt Minecraft EDU (Minecraft: Education Edition, 2017a). Jeg har også utviklet læringsmateriell for spillet på oppdrag fra Medietilsynet og Senter for IKT i utdanningen (Medietilsynet, udatert). Min forskningsinteresse for Minecraft: Education Edition springer med andre ord ut av omfattende erfaring med tidligere versjoner av Minecraft, hvor ansvaret for å gjøre spillet relevant i en læringskontekst var tydeligere plassert hos læreren, og ikke lå i programvaren selv. 
Min erfaringsbakgrunn som både dataspiller og dataspill-lærer er ikke uvesentlig når jeg med denne analysen trer inn i en tredje rolle, nemlig som forsker. Sammen danner de tre basis for min egen subjektivering i møte med objektet «spillbasert læring». Med bakgrunn i de tre nevnte rollene har jeg en forståelse av selv å ha vært med på å skape diskursen "dataspill i skolen», jeg har en rekke oppfatninger om hvordan den har oppstått, hva som preger den i dag og hvilket potensiale den har til å påvirke skole og læring i framtida. Som lærer hadde jeg også en forståelse av meg selv som en lærer som forsto dataspill fra en spillerposisjon, og nå ser jeg på meg selv som en skoleforsker som undersøker både skole og læring fra en lærerposisjon. Alt dette er med på å forme mitt blikk, både på teoriene jeg støtter meg til i min analyse, og på spillet og undervisningsoppleggene jeg analyserer.

\section{Minecraft i et didaktisk perspektiv}

Forskning på bruken av Minecraft i skolen domineres av casestudier med didaktisk orientering (Nebel, Schneider \& Rey, 2016). En del studier har fokusert på spillets muligheter og praksiser knyttet til samarbeidslæring, både for elever og lærere (Dodgson, 2017; Kuhn \& Stevens, 2017; Davis, Boss \& Meas, 2018). Andre har utforsket læreres kompetansebygging, rolleforståelse og didaktiske muligheter til å legge opp god undervisning (McColgan, Colesande \& Andrade, 2018; Ellison \& Evans, 2016). Det har hittil ikke vært publisert mye forskning på bruk av Minecraft: Education Edition.

Funnene i forskningen på Minecraft i skolen har gjerne bekreftet at spillet både øker motivasjon og læring (Nebel, Schneider \& Rey, 2016). Det er stor enighet om at spillet fremmer en konstruktivistisk pedagogikk og oppmuntrer til utforskning, samarbeid og frihet. Bos, Wilder, Cook og O'Donnel (2014) er et eksempel på dette, men de peker også på en mulig begrensning $\mathrm{i}$ at elevene ikke alltid forstår hvilke spørsmål og problemer de skal jobbe med i spillet. De hevder at det er her læreren kan bidra med meningsfulle scenarier og relevante, pensumrelaterte spørsmål (Bos et.al., 2014, s. 57). Denne konklusjonen fra Bos et al. er interessant i lys av Nebel et al.s (2016) betraktning, om at et mulig problem med å bruke spillet i skolen kan være at spillet er ment å være svært åpent, basert på spillerens egendefinerte mål, og med et fokus på utforskning og oppdagelse. Å bruke spillet til å nå læringsmål i skolen kan dermed være "an aim that somehow violates the core principle of the game" (Nebel et al., 2016, s. 360). Nebel et al. peker her på en utfordring jeg forsøker å utforske nærmere i denne studien.

\section{Maktens mikrofysikk}

Denne studien er inspirert av Foucaults analyse av makt. I hans begrep maktens mikrofysikk ligger det at maktforhold finnes i alle relasjoner, og at maktutøvelse derfor verken er ond eller unngåelig (Eliassen, 2016, s. 132). I forelesningsrekken La Societe 


\section{H. Sandberg}

Punitive beskrev Foucault hvordan «formålet med å prege rommet gjennom utforming og overvåking er å tøyle kroppenes krefter» (Eliassen, 2016, s. 120). Når læringsaktivitet flyttes fra fysiske rom inn i digitale, skjer det også her en utforming og en overvåkning som har til hensikt å sikre at de som er tilstede med sine «digitale kropper», gjerne kalt avatarer (Klevjer, 2006), tøyles og ledes inn i aktivitet som anses konstruktiv, sett ut fra læringsmålene. Denne studien dreier seg om hvilke verktøy læreren har til rådighet for denne utformingen og overvåkingen i Minecraft: Education Edition, og hvordan verktøyene blir brukt i tre undervisningsopplegg.

Verktøyene gir læreren anledning til å utforme og overvåke det digitale rommet i en svært konkret forstand. Så konkret at man kan spørre seg om ikke de av Foucaults beskrivelser som ofte leses metaforisk, blir mer virkelige når de brukes om en virtuell verden enn om samfunnsforhold i den fysiske verden. Et sentralt eksempel er panopticon, som Foucault først beskrev som en konkret overvåkingsarkitektur i fengsler og andre anstalter i boka Surveiller et punir. Naissance de la prison (Foucault, 1977), før begrepet fikk en mer metaforisk funksjon da det ble knyttet til beskrivelsene av dispositiver og selvets teknologi. I denne studien av pedagogisk spillteknologi, ser jeg på panopticon og andre aspekter av maktens mikrofysikk, på den samme konkrete måten som den tidlige Foucault (Eliassen, 2016, s. 133). En årsak til det er at den undervisningsvirkelighet jeg beskriver, der virtuelle kropper og rom har erstattet de fysiske, allerede ligger på et «semi-metaforisk» plan. Overvåkning her dreier seg ikke om å overvåke elevenes egne kropper, men deres avatarer. Både elevene selv, læreren og jeg som forsker finner det naturlig å betegne disse med personlige pronomen, altså elevene personifisert, når vi refererer til spilløkta.

\section{Diskurser, subjekter og objekter}

I analysen bruker jeg noen sentrale operasjonelle begreper fra Faircloughs (Fairclogh, 1993) kritiske diskursanalyse (CDA) og Parkers (Parker, 1992, 1994) «foucaultske» diskursanalyse (FDA). Begge hører til metodologiske skoler som er grunnleggende politiske i forståelsen av språk som makt (Wooffitt, 2005). Parker, for eksempel, forstår diskurser som «systems of meanings which reflect real power relations, and which in turn are a consequence of the material and economic infrastructure of society» (Wooffitt, 2005, s. 147). Det passer med min lesning av Foucault, som jeg har redegjort for ovenfor, og utgjør et rasjonale for meg til å bruke dem.

Spillelementene jeg analyserer er de sentrale verktøyene Minecraft: Education Edition tilbyr for å legge til rette for bruk av spillet i skolen. Å analysere disse i et maktperspektiv innebærer ikke en kritikk av Minecraft: Education Edition eller lærere som bruker denne versjonen av spillet. Snarere tvert imot; det at lærere velger å erstatte mer tradisjonelle undervisningsmetoder med skapende aktivitet $\mathrm{i}$ et dataspill, vil i mange tilfeller innebære en utvidelse av elevens makt over undervisningssituasjonen. Når jeg sammenlikner spilling av Minecraft i og utenfor undervisning, derimot, ser det ut til at spilleren nødvendigvis mister makt når spillet skal tjene et læringsformål. 
Jeg kan altså se konturene av to diskurser her: en spilldiskurs og en skolediskurs. Minecraft: Education Edition kan dermed beskrives som en interdiskursiv tekst (Fairclough, 1993, s. 137). Måten man snakker om spill på varierer med andre ord med konteksten man giør det i. Et læringsspill er noe annet enn et underholdningsspill, også i de tilfeller hvor selve spillet er det samme.

Diskursbegrepet er ellers komplekst og mangetydig, og kan derfor være vanskelig å bruke. Med støtte i Faircloughs beskrivelse av «diskursive hendelser» forstår jeg begrepet i kontekst av mine få utvalgte tekster. Disse betrakter jeg som «tilfeller av språkbruk», uten å verken avvise eller måtte forholde meg til de videre "orders of discourse» tekstene er del av, men som faller utenfor fokuset i min undersøkelse (Fairclough, 1993, s. 135). Parkers definisjon av diskurser som "sets of statements that construct objects and an array of subject positions", gir meg et tilsvarende konkret verktøy for å fokusere undersøkelsen (Parker, 1994, s. 245). I beskrivelsen av subjektsposisjoner ligger en klargjøring av hvordan subjektene kan posisjonere seg i forhold til de diskursive objektene, og $\mathrm{i}$ hvilke diskurser. Med dette som utgangspunkt vil jeg fokusere på å beskrive objekt og subjektsposisjoner som er aktuelle for læringsdiskursen.

\section{«Education edition»: Spillets læringsfunksjonalitet og bruken av den}

Der tradisjonelle læreverk gjerne er utstyrt med en lærerveiledning, har utgiveren av Minecraft: Education Edition opprettet nettstedet https:/education.minecraft.net/. Dette er den offisielle hjelperessursen for spillet. Her finner lærere som vil bruke spillet i undervisning inspirasjon og informasjon om hvordan de kommer $i$ gang. Nettstedet er også et sosialt møtested for lærere som bruker spillet, hvor de registrerer seg med egne profiler og kan dele ideer, erfaringer og undervisningsopplegg for bruk av Minecraft: Education Edition. De fleste undervisningsoppleggene som ligger tilgjengelig på nettstedet er laget og delt av lærere.

I denne studien analyserer jeg både informasjon om spillet som utgiveren har publisert på nettstedet, og undervisningsopplegg lærere har delt der. Disse kan betraktes som to forskjellige typer av diskursive hendelser der forutsetningene er ulike (Fairclough, 1993). Utgangspunktet for analysen av undervisningsoppleggene, er en tekst som beskriver de viktigste forskjellene mellom skoleversjonen av Minecraft og den ordinære versjonen av spillet. Teksten er skrevet av utgiverne av spillet, og omtaler elleve spillelementer. Jeg identifiserer fem av disse som relevante for lærerens kontroll over selve spillingen. Før jeg kommer inn på undervisningsoppleggene presenterer og diskuterer jeg disse fem. Deretter går jeg gjennom tre undervisningsopplegg som er laget av lærere, for å se hvordan spillelementene blir brukt. Undervisningsoppleggene er langt mer personlige tekster, laget av lærere som fortellinger om egen pedagogisk praksis og som anbefaling til kolleger, og delt under eget navn på nettsamfunnet. Undervisningsoppleggene skiller seg også fra utgiverens tekst ved at de innebærer fortolkninger av de muligheter som er gitt i den teknologien som er laget av noen andre. 


\section{H. Sandberg}

Da jeg valgte ut undervisningsoppleggene var det derfor et sentralt kriterium at de ikke skulle være laget av spillutvikleren; jeg ville se hvordan lærere fortolket og kanskje så andre muligheter i funksjonaliteten. Jeg antok at spillutviklerens egne undervisningsopplegg (som også er delt på nettstedet) ville være mer i tråd med den beskrevne bruken av spillelementene. Jeg har ikke undersøkt om dette faktisk er tilfelle. Andre utvalgskriterier var at oppleggene var laget for ulike fag og trinn i skolen, motivert av et ønske om å se en variasjon av bruk av spillelementer. Hvert undervisningsopplegg er beskrevet i en lærerveiledning. Ett av dem er knyttet til en egen spillverden i form av en nedlastbar datafil, og i et annet er det lagt en veiledningsvideo på YouTube.

Den spesiallagde spillverdenen som et av oppleggene er bygget rundt, er en modell av Verona sånn William Shakespeare beskrev det i dramaet Romeo og Fulie. Å «lese» en spillverden som en kompleks digital tekst skiller seg fra lesing av både tradisjonell tekst og nyere medieuttrykk som film på flere vis, men kan gjøres i tråd med Parkers anbefaling om å «consider all tissues of meaning as text» (Parker, 1992, s. 7). Måten jeg valgte å gjennomføre denne digitale ekskursjonen på, var å filme skjermen mens jeg spilte. Det ga meg mulighet til å gå tilbake og se materialet igjen. Jeg kommenterte også mens jeg spilte, og fikk på den måten en spontan fortolkning av det jeg så i lydsporet. Her er et eksempel fra min første utforskning av Verona: https://youtu.be/ RedDt0TtKxU

Undervisningsoppleggene er sammensatte tekster som både er sosialt formet og sosialt formende (Fairclough, 1993, p. 134). Det første fordi de er laget av lærere, ikke av spillutvikleren, samtidig som de nødvendigvis må følge premisser gitt av utvikleren. Det andre fordi de blir presentert på nettstedet (av utvikleren) som «best practice»eksempler for lærere over hele verden. De tre undervisningsoppleggene er sammenlignbare fordi de er praktiserende læreres fortolkninger og tilpasninger av utviklerens produkt. I analysen forsøker jeg å beskrive hvordan spillelementene er laget for å forme en praksis, og hvordan undervisningsoppleggene i ulik grad bekrefter, videreutvikler eller står i motsetning til disse intensjonene. Resultatet av prosessen er at det dannes subjektsposisjoner for lærerne som til slutt tar spillet og undervisningsoppleggene i bruk.

\section{Fem spillelementer}

Minecraft: Education Edition har, i likhet med det ordinære Minecraft, ikke noen tradisjonell spillmanual. I seksjonen «Support/Knowledge base» på nettstedet finnes det imidlertid en oversikt over spillelementer som er eksklusive for utdanningsversjonen av spillet (Minecraft: Education Edition, 2017b). Det er elleve i alt, men ikke alle er relevante for denne studien. De jeg velger bort dreier seg om teknisk tilpasninger (sikker innlogging og mulighet for å spille sammen uten bruk av ekstern server), kreative muligheter utenfor spillet (3D-eksport av byggverk) og ressurspakker for spesifikke kunnskapsdomener (kjemi og koding). 
De fem resterende spillelementene er designet for å gi læreren kontroll over spillet og spillerne. Jeg skal se nærmere på hvordan disse presenteres og hvilke muligheter de gir læreren for kontroll. Senere skal jeg se på hvordan dette endrer seg gjennom måtene de blir brukt på i de tre undervisningsoppleggene.

Knowledge Base > Game Features > Features of Minecraft: Ed...

\section{FEATURES OF MINECRAFT: EDUCATION EDITION}

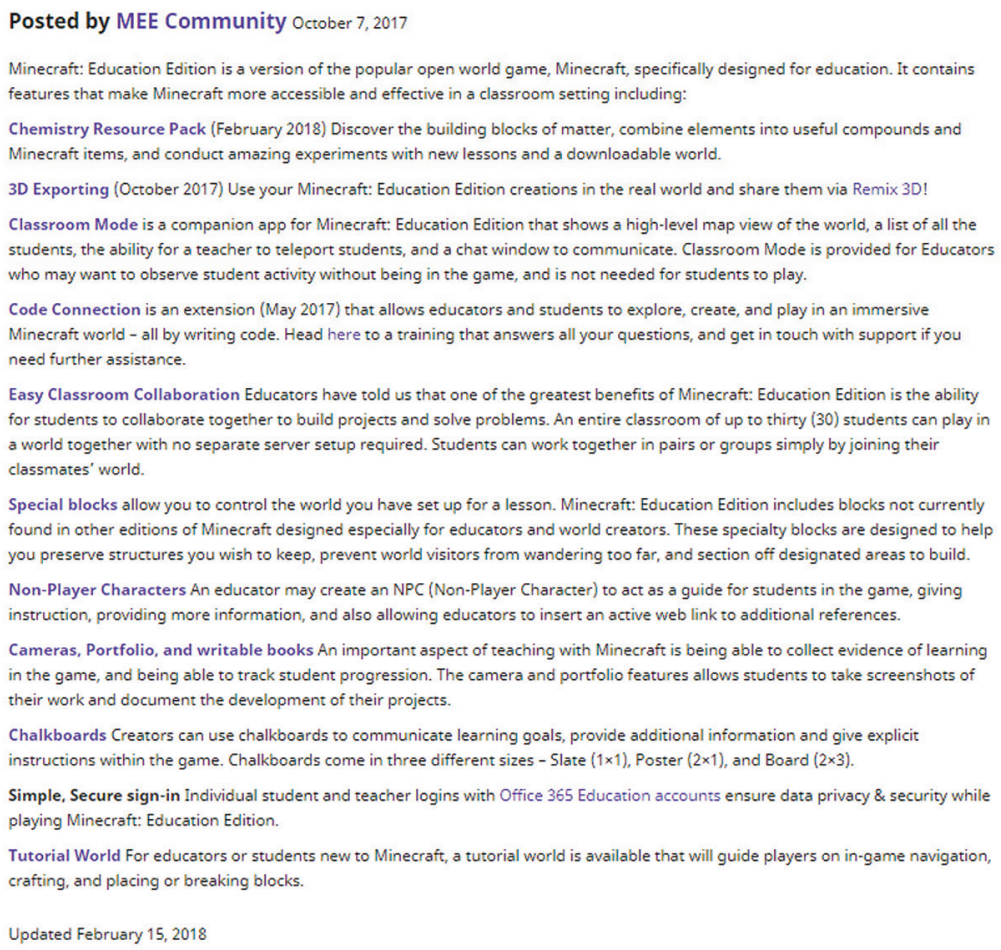

Illustrasjon 2. Skjermdump fra https://education.minecraft.net/support/knowledge-base/features/

Nedenfor gjengir jeg beskrivelsen av de fem spillelementene som fungerer som verktøy for utforming og overvåking av spillverdenen, hver fulgt av en kort analyse som også uttrykker min forståelse av hvordan hvert av elementene er tenkt brukt. Dette er utgangspunktet når jeg senere skal se på hvordan de faktisk blir brukt i tre undervisningsopplegg. 


\section{H. Sandberg}

Classroom Mode is a companion app for Minecraft: Education Edition that shows a high-level map view of the world, a list of all the students, the ability for a teacher to teleport students, and a chat window to communicate. Classroom Mode is provided for Educators who may want to observe student activity without being in the game, and is not needed for students to play.

Classroom mode er ikke et element som syns i spillet, men en app som gir læreren anledning til å se spillaktiviteten utenfra, samt snakke med og flytte på elever. I Foucault-termer kan man si at Classroom mode gjør hele spillverden til en panopticon, hvor læreren kan se alt som skjer uten selv å bli sett (Eliassen, 2016, s. 131). Det er også denne appen som gjør det mulig for lærere som mangler grunnleggende spillkompetanse å styre et undervisningsopplegg i spillet uten selv å måtte delta som avatar.

Special blocks allow you to control the world you have set up for a lesson. Minecraft: Education Edition includes blocks not currently found in other editions of Minecraft designed especially for educators and world creators. These specialty blocks are designed to help you preserve structures you wish to keep, prevent world visitors from wandering too far, and section off designated areas to build.

Mens Classroom mode er et verktøy for å overvåke og kontrollere spillere direkte, er Special blocks et knippe verktøy for å kontrollere omgivelsene. Border blocks lager en usynlig grense spillerne ikke kommer seg gjennom. Det brukes for å sperre spillere ute fra eller inne i et område. Deny/Allow blocks gjør at læreren kan bestemme om et område kan eller ikke kan bygges på. I tillegg til at disse elementene gir læreren stor kontroll på hva elever kan bygge eller ødelegge, gjør de læreren i stand til å lage opplegg og utfordringer som går på helt andre ting enn bygging. Dersom læreren for eksempel vil lage et hus elevene skal besøke, kan hun med disse blokkene hindre at noen ødelegger huset eller begynner å endre eller innrede det. Jeg velger i den videre analysen å omtale Special blocks som én enhet der det er mulig, og de enkelte delfunksjoner spesifikt der det er nødvendig. I tillegg til de som er nevnt finnes Structure blocks, som brukes til å eksportere ting som er laget i Minecraft: Education Edition, så man kan 3D-printe dem eller se dem i et 3D-program utenfor spillet. Disse er holdt utenfor denne undersøkelsen (Minecraft: Education Edition, 2017c).

Non-Player Characters. An educator may create an NPC (Non-Player Character) to act as a guide for students in the game, giving instruction, providing more information, and also allowing educators to insert an active web link to additional references.

Non-player characters (forkortes gjerne til NPC, noe jeg også gjør videre i denne artikkelen) er personer som kan forhåndsprogrammeres av læreren, men deretter styres av spillet. Slike er det mange av i dataspill, hvor de blant annet kan bidra til å skape dybde $\mathrm{i}$ en historie, vise vei eller veilede spilleren i utførelsen av et oppdrag. I Minecraft: Education Edition vil de også kunne fungere som en portal over til ressurser på 
internett. I kontrast til Classroom Mode er dette en måte å påvirke spillet på som er synlig for spilleren, og passiv fordi spilleren selv må henvende seg til NPC'en. Bruk av NPC kan også fremme situert læring ved at det som formidles på denne måten gjerne bakes inn i spillets fortelling og kontekst (Gee, 2006).

Chalkboards. Creators can use chalkboards to communicate learning goals, provide additional information and give explicit instructions within the game. Chalkboards come in three different sizes - Slate $(1 \times 1)$, Poster $(2 \times 1)$, and Board $(2 \times 3)$.

Chalkboards er tavler læreren plasserer ut i spillverdenen og skriver på. Disse kan brukes både til veivisning og praktiske instruksjoner, så vel som til å formidle faglig kunnskap. Jeg registrerer at utviklerne har valgt å kalle det "chalkboards", krittavle, og på den måten knytte det til den tradisjonelle skoleteknologien de forsøker å erstatte, og som også Foucault har brukt som eksempel på opplysningstidens disiplinerende og kontrollerende teknologi (Eliassen, 2016, s. 127).

Funksjonene chalkboards skal fylle er sterkt overlappende med oppgavene man kan gi en NPC. Det er derfor grunn til å tenke at de to til sammen giør spillet attraktivt for lærere med ulike preferanser, kanskje med ulike subjektsposisjoner i forhold til det diskursive objektet læring: lærere som er fortrolige med og liker spill (rollespill eller dataspill) kan befolke sin verden med NPC'er, og lærere som er mer orientert mot formidlingspedagogikk kan fylle sin Minecraft-verden med krittavler. Det er imidlertid på sin plass å påpeke at tradisjonell skoleteknologi som Chalkboards også er i tråd med Minecrafts uttrykk ellers; spillet inneholder mange tradisjonelle, nostalgiske objekter i digital form.

Cameras, Portfolio, and writable books. An important aspect of teaching with Minecraft is being able to collect evidence of learning in the game, and being able to track student progression. The Camera and Portfolio features allows students to take screenshots of their work and document the development of their projects.

Spilleren kan skrive tekst i bøker inne i spillet, og eksportere dem for bruk utenfor spillet (f.eks. som innlevering til læreren). Det finnes også en kamerafunksjon hvor de kan ta bilder av det de ser i spillverdenen (f.eks. noe de selv har laget). De kan også sette opp et kamera med selvutløser og ta bilde av seg selv og omgivelsene sammen. Bilder og/eller tekst kan videre samles i en bok/portfolio og eksporteres som en fil som sendes til læreren. Dette er det eneste spillelementet hvor elevene omtales som brukere. Tidligere i denne teksten har bare læreren vært beskrevet som aktiv. I likhet med når jeg omtaler Special Blocks, velger jeg som hovedregel å omtale de tre dokumentasjonsverktøyene samlet som ett spillelement, men spesifiserer når det trengs.

\section{Spillets posisjonering av læreren}

Gjennomgangen ovenfor kan bli brukt til å konstruere diskursive objekter; språklige konstruksjoner som lærere posisjonerer seg i forhold til (Parker, 1994). Hvis man går ut fra at det sentrale diskursive objektet for et læringsspill er "læring» (alternativet 


\section{H. Sandberg}

ville være "spill», og vi som mener at det er et like relevant objekt i en skolekontekst, er nok fremdeles i mindretall), kan man se hvordan hvert spillelement bidrar til dannelsen av dette objektet, og hvordan det framstår for subjektene som skal forholde seg til det.

Læring er i disse beskrivelsene i stor grad konstruert av lærerens forberedelser i forkant og kontroll underveis, og elevens mindre definerte læringsaktivitet innenfor rammene som er satt av lærere. Subjektsposisjonen spillet tilbyr læreren, dreier seg om å forstå læring som noe læreren kan forberede gjennom å bestemme hvor i den virtuelle læringsverdenen aktiviteten skal skje, og hvor stort areal den skal kunne strekke seg over, definere forbud og tillatelser innenfor dette området og forberede instruksjon og informasjonsressurser i verdenen. For læreren vil det også være del av forberedelsen å tilgjengeliggjøre, samt gi instruksjoner om bruk av verktøy for dokumentasjon av læringsprosessen. Underveis i undervisningen innebærer læring å holde oversikt og kontroll med elevene, og å veilede og flytte på dem. Dette kan gjøres fra et eksternt dataprogram, hvilket betyr at undervisning/veiledning ikke nødvendigvis innebærer å delta i aktiviteten eller være synlig tilstede i det virtuelle rom hvor den foregår.

Selv om elevenes læring naturligvis også er lærerens mål med undervisningen, viser gjennomgangen av spillelementer at det i stor grad er lærerens metoder, ikke elevens tenkning og forståelse programvaren støtter opp om. Deler av utviklerens omtale av de fem spillelementene tyder på at spillet er laget for å ivareta formidlingspedagogikken og lærerens sentrale og allestedsnærværende rolle også i dette digitale klasserommet. Dette kommer særlig tydelig til uttrykk gjennom appen Classroom Mode, men også ved at de har beholdt krittavla, og at elevaktiviteten som omtales dreier seg om å forholde seg til lærerens instruksjoner, få informasjon og dokumentere arbeidet sitt. Læreren tilbys med andre ord en subjektsposisjon som en initierende og kontrollerende instans, mens elevenes først og fremst framstilles som respondenter til lærerens initiativ.

Spillelementet NPC viser at det også blir lagt til rette for formidlingsformer særegne for dataspill. Det kan være et uttrykk for at utvikleren har sett for seg at noen av lærerne har spillerfaring og søker mer spillnære funksjoner, eller det kan være et mer generelt ønske om å bruke spillenes tradisjonelle formidlingsformer. I alle tilfeller viser det at utvikleren tilbyr variasjon i hvordan lærere kan bruke spillet, samtidig som det ser ut til at det har vært viktig å beholde muligheten for å holde "stramme tøyler» i undervisningen. Det at NPC-funksjonen er så sterkt overlappende med funksjonene til den mer tradisjonelle krittavla, styrker en slik tolkning.

Beskrivelsene av spillelementer ovenfor er uttrykk for hvordan utvikleren tenker seg at de kan bli brukt. Latour minner oss på at «the fate of a statement is in the hands of others» (Latour, 1991, s. 105-6). I neste del av analysen skal jeg følge spillelementene over i en ny diskursiv hendelse (Fairclough, 1993), fra utviklerens erklæring om hvordan de er tenkt brukt til den konkrete og situerte bruken i lærernes undervisningsopplegg. 


\section{Spillelementene i bruk}

Jeg skal nå se på tre undervisningsopplegg som bruker Minecraft: Education Edition, med vekt på hvordan de tar i bruk de fem spillelementene jeg analyserte ovenfor. De tre undervisningsoppleggene er rettet mot ulike fag og aldersgrupper: et opplegg i matematikk for mellomtrinnet, et i biologi for ungdomstrinnet, og et drama/ litteratur-opplegg laget for elever i videregående skole. Dermed har naturligvis de tre oppleggene ulike læringsmål, og dette vil påvirke hvordan hvert av dem bidrar til å danne det diskursive objektet «læring». De tre undervisningsoppleggene heter Fraction Stories, Verona Adventure og Create Fred the Human Body. Tabell 1 gir en oversikt over bruken av Education Edition's spillelementer i de tre.

\begin{tabular}{|l|l|l|l|}
\hline Tittel & Verona Adventure & Fraction Stories & Create Fred the human body \\
\hline NPC & $\begin{array}{l}\text { Byen er full av personer } \\
\text { eleven kan snakke med. } \\
\text { De fleste svarer med } \\
\text { informasjon, i ett tilfelle } \\
\text { svarer en NPC med å } \\
\text { teleportere spilleren i } \\
\text { fengsel, og i et par andre } \\
\text { med å åpne en ressurs på } \\
\text { internett. }\end{array}$ & $\begin{array}{l}\text { En som bor i huset. } \\
\text { han skal si noe. }\end{array}$ & Ikke brukt. \\
\hline Chalkboard & $\begin{array}{l}\text { Brukes som veiskilt i } \\
\text { Verona. }\end{array}$ & $\begin{array}{l}\text { Brukes av læreren } \\
\text { til å beskrive } \\
\text { arbeidsoppgaven(e) og } \\
\text { av elevene til å skrive } \\
\text { sin historie. }\end{array}$ & $\begin{array}{l}\text { Brukes av elevene til å beskrive } \\
\text { kroppsorganers funksjon. }\end{array}$ \\
\hline Portfolio, \\
Notebook
\end{tabular}

Tabell 1. En oversikt over de tre oppleggene og hvordan spillelementene er brukt.

Verona Adventure, heretter omtalt som VA, har følgende læringsmål:

- Students will gather evidence from multiple in-game sources.

- Students will determine credible sources.

- Students will use evidence in an argumentative essay.

(Spieldenner \& Baddeley, 2018)

VA er et mysteriespill lagt til Verona i tiden etter at handlingen i Shakespeares Romeo og Fulie har utspilt seg. Spillerne skal avdekke en historie om nye konflikter som har 


\section{H. Sandberg}

oppstått mellom Montague og Capulet-familiene. De må utforske en digital rekonstruksjon av byen, samle informasjon gjennom samtaler med NPC'er, notere og ta bilder av bevismateriale de finner. Her brukes spillelementene omtrent på den måten de blir beskrevet av utvikleren. En modell av Verona er laget på forhånd og ikke mulig å endre av elevene. NPC'ene er forhåndsprogrammert med dialoger spilleren kan ha med dem, og spillerne er utstyrt med Camera og Portfolio for å samle inn informasjon. De som har laget opplegget har brukt Minecraft til å bygge en spillverden, og elevenes oppgave er ikke å bygge, men å utforske byen.

I dette opplegget er læring assosiert med å utforske og oppdage. NPC-ene er gitt roller hvor de har ulike tanker og meninger knyttet til en større fortelling, og informasjon som utgjør et fragment av en helhet. Eleven skal samle mange nok av disse bitene til å forstå fortellingen. Dermed handler læring her om å bruke og forholde seg til ulike kilder, og skape en helhet av det. Spilløkta har et etterarbeid hvor elevene skal skrive et "argumentativt essay». Skrivearbeidet foregår utenfor spillet, men oppgaven blir gitt til eleven av en NPC i spillet. Læring her er dermed i stor grad et spørsmål om å øve ferdigheter. Samtidig relateres historien til fortellingen om Romeo og Julie, og dreier seg på den måten om å jobbe med spørsmål knyttet til klassisk litteratur. I stedet for å simulere virkeligheten inne i spillet (som f.eks. i CFTHB som beskrives nedenfor), flyttes her spillets historie ut, og lar eleven gjøre et arbeid utenfor spillet som relateres til opplevelser de har hatt innenfor.

Fraction story, heretter omtalt som FS, har følgende læringsmål:

- Students will learn about different aspects of fractions (before making their fraction story).

- Students will show understanding of how fractions are used in their everyday life and language.

- Students will demonstrate clear communication of math work.

(Borregaard, 2016)

Dette opplegget beskrives kun i en lærerveiledning, og har ikke noen egen verden-fil for nedlasting. Målet er å lære fraksjoner/brøkregning og opplegget begynner med at elevene skal lære konseptet gjennom tradisjonell undervisning og øvelse. Deretter skal de lage «fraksjonshistorier» i Minecraft: Education Edition, ved at lærer gir dem "world builder»-rettigheter, dvs. de samme rettighetene som læreren selv har til å administrere spillverdenen. Deretter er det elevene selv som befolker historiene sine med NPC-er og Chalkboards hvor historien fortelles.

I FS bygges den konseptuelle forståelsen av temaet opp før elevene begynner å spille. Forberedelsen omfatter både fraksjoner skrevet med tall og tegnet på ruteark. Den påfølgende aktiviteten i spillet dreier seg om å ta denne teorien i bruk. Da er det numeriske uttrykket for fraksjonene å finne på Chalkboards, mens det visuelle uttrykket (tilsvarende rutearket) gjenskapes med klosser i ulike farger og materialer i spillet. I FS foregår altså ikke selve innlæringen i spillet, spillet er mediet for å 
jobbe med teorien og relatere den til en mer virkelighetsnær situasjon. Det er denne NPC-en bidrar til å skape, ved at han bor i huset som skal bygges med ulike fraksjoner. Chalkboards bidrar til å bringe inn det ikke-visuelle aspektet, mens Camera/ Portfolio-verktøyene brukes til å dokumentere fraksjonshistoriene. Læringsobjektet dreier seg da om å relatere teori til noe mer virkelighetsnært, i tillegg til at det dreier seg om å repetere og relatere kunnskapen til ulike kontekster. Læring er her å kombinere teoretisk kunnskap med praktisk bruk.

Create Fred the human body, heretter omtalt som CFTHB, har følgende læringsmål:

- Identify parts of the body and describe and display their purpose.

- Communicate ideas, explanations and processes in a variety of ways, including multi-modal texts.

- Collaborate to create a single human body with significant organs and systems represented.

- Use project based learning techniques.

(Telfer, 2016a)

I dette opplegget får en hel klasse i oppdrag å samarbeide om å lage en liggende menneskekropp med mest mulig realistiske modeller av indre organer. I likhet med Fraction Story finnes det ingen forhåndslaget verden å laste ned. Læreren foreslår å bare opprette en verden bestående av en helt flat gressplen og deretter skisse deler av kroppen for å indikere størrelsen. Her anbefaler hun at noen få elever skal få "world builder»-rettigheter, og at de aktivt bruker Chalkboards til å skrive beskrivende tekster ved siden av de ulike organene de bygger. I tillegg har denne læreren en egen måte å starte aktiviteten på: Hun beskriver hvordan læreren kan bestemme «spawn point» $\mathrm{i}$ spillet, dvs hvor spillerne kommer inn i spillet når de starter. Bestemmelse av spawn point er et spillelement jeg ikke har omtalt tidligere da det ikke er eksklusivt for Minecraft: Education Edition. Deretter anbefaler hun å bygge Border Blocks rundt dette punktet, og Deny Blocks i bakken. På den måten havner alle spillere i et slags bur straks de starter spillet. Derfra kan de verken rømme eller begynne å grave eller bygge. Den tilstanden varer imidlertid bare til alle har kommet seg inn og hun har fătt gitt noen få nødvendige beskjeder før hun, i egne ord, «slipper fangene fri» (Telfer, 2016b).

Opplegget kan beskrives som en digital formingsoppgave der materialet er Minecrafts ulike byggeklosser og funksjoner. Måten spillelementene brukes på, bidrar til å konstruere objektet «læring» i tråd med dette. Sentrale læringsmål er å vise menneskelige organer og beskrive deres funksjon. Til det første bruker de Minecrafts grunnleggende bygge-funksjonalitet, og til beskrivelsene bruker de Chalkboards. Læring i dette opplegget, dreier seg med andre ord om å ta med teoretisk kunnskap inn i en Minecraft-verden, uttrykke den på representasjoner av den tradisjonelle formidlingsteknologien "tavle», og visualisere kunnskapen med Minecrafts klosser og funksjoner. CFTHB tar ikke i bruk NPC-er da det ikke er noe element av rollespill i 


\section{H. Sandberg}

dette opplegget. Bruken av Special Blocks og spawn point i begynnelsen illustrerer at klasseledelse er nødvendig, men ikke trenger å være tidkrevende eller prege mye av elevenes spilltid. Denne kortvarige disiplineringen av elevene kan også ses på som sosial læring.

\section{Oppsummering: spillelementene i bruk}

Ser jeg samlet på hvordan hvert spillelement brukes i oppleggene, kan jeg altså se at NPC-er brukes i rollespill-sammenhenger og utstyres med funksjonalitet etter behov. I undervisningsopplegget hvor rollespill er sentralt og bærende for undervisningsopplegget, brukes all tilgjengelig funksjonalitet og gjør karakterene komplekse. I opplegget hvor karakterens eneste «egenskap»er at han bor i huset, brukes ingen funksjonalitet utover karakteren selv. I opplegget som ikke er et rollespill, brukes ikke NPC-er overhodet.

I begge de realfaglige oppleggene, hvor faglige fakta er sentralt, brukes Chalkboards til å formidle disse. I rollespillet i Verona brukes de som veiskilt i byen. Special blocks brukes ulikt i oppleggene. I den forhåndslagde rollespillverdenen hvor elevene ikke skal bygge, brukes special blocks for å hindre bygging og sabotasje. I et av byggeprosjektene brukes de en kort stund for å samle elevene og sikre at de starter likt. I det siste opplegget brukes de ikke. I begge byggeprosjektene brukes Camera av lærer eller elever til dokumentasjon av byggeprosessen. I rollespillet i Verona brukes både det og Notebook av elevene som verktøy i deres egen utforskning/etterforskning av historien.

De tre undervisningsoppleggene tar altså spillelementene i bruk på varierte måter, og gjør på den måten «læring» til et komplekst diskursivt objekt. Dette forsterkes også av at undervisningsoppleggene er bygget rundt læringsmål, mens den generelle beskrivelsen av spillelementer (illustrasjon 2) bare kunne handle om læring i veldig generell forstand.

Vi ser at spillet fyller andre funksjoner i de realfaglige oppleggene i forhold til i de humanistiske. Mens spillet blir et sted for «arbeidsoppgaver» til gjennomgått teori i FS og dels i CFTHB, blir det i VA stedet hvor elevene henter informasjon som så behandles videre utenfor. Mens elevene i VA spiller alene i en nøye preparert verden uten lærerens (synlige) deltakelse, blir de, eller noen av dem, i de to øvrige oppleggene utstyrt med fulle rettigheter til å redigere og endre en verden der lite eller ingenting er forberedt for dem. I CFTHB skjer dette i samarbeid med en lærer som konsekvent omtaler seg selv som del av gruppa.

Ellers viser de tre undervisningsoppleggene en variasjon i utforming og bruk av spillelementer, som vitner om at de som har laget dem er styrt av egne kreative ideer og didaktiske muligheter, og ikke begrenset av hvordan spillelementene er beskrevet i veiledningen. Det virker også frigjørende på subjektsposisjonene. For elevene er det store muligheter for samarbeid og leken faglig aktivitet, muligheter til å bruke lærerens redigeringsverktøy eller kanskje bli hjelpelærer. Læreren kan velge å bruke spillelementer som gir muligheter til grundig forberedelse, kontroll og oversikt 
over aktiviteten, eller hun kan opprette en enkel verden og sette i gang aktivitet der sammen med elevene.

\section{Diskusjon}

Jeg har vist at utviklerens beskrivelse av spillelementene i stor grad legger opp til at det er læreren som initierer aktivitet. Dette kan illustreres ved å liste opp de aktive verbene i den korte teksten. Da finner jeg at læreren teleports, communicates, observes, controls, preserves, prevents, sections off, creates, provides, gives, collects og tracks. Elevaktiviteten er beskrevet giennom bare tre verb: Eleven communicates [med læreren], documents [til læreren] og plays. Dette kan forklares med at teksten er ment å henvende seg til lærere som vurderer å bruke spillet. Likevel, hvis man skal ta beskrivelsene på alvor er det grunn til å hevde at disse spillelementene, som er det som skiller Minecraft: Education Edition fra vanlig Minecraft, er med på å gi læreren en subjektsposisjon som både initierer læringsaktiviteten og har full oversikt og kontroll over den.

Undervisningsoppleggene nyanserer en slik forståelse. I FS og CFTHB beskrives lærerrollen som aktiv og tilstede sammen med elevene, aller mest i sistnevnte, der hele opplegget er beskrevet i en «vi»-form som omfatter både læreren og elevene. VA skiller seg ut ved at spillverdenen allerede er skapt, og opplegget er laget for enkeltelever som skal utforske Verona alene gjennom en lang økt (ca. 90 minutter). Opplegget legger dermed opp til en ganske passiv lærerrolle, i hvert fall fram til helt på slutten, hvor spillet setter spilleren til å skrive en argumenterende tekst. Da, om ikke før, går læreren inn i en kjent veilederrolle.

Analysen av de tre undervisningsoppleggene viser også at flere av elementene blir brukt på andre måter enn slik de er beskrevet i brukerveiledningen. Mens NPC-er er forhåndsplassert og gitt replikker i VA, slik utvikleren har foreskrevet, får elevene selv plassere dem og dikte dem inn i fortellingene sine i FS. Likeledes brukes Chalkboards $i$ både FS og CFTHB underveis i spillaktiviteten, ikke til å gi informasjon, instruksjoner og læringsmål, men som medier hvor elever selv kan forfatte fortellinger og fagtekster. Structure Blocks brukes som "foreskrevet» $i$ et minutt eller to helt $i$ begynnelsen av CFTHB, for å hindre at noen vandrer av gårde eller bygger der de ikke skal bygge. Deretter slippes elevene fri fra stengslet og dette spillelementet brukes ikke mer. I opplegget som er mest tro mot den foreskrevne bruken, VA, er Minecraft ikke et byggespill, men et historiedrevet spill om å utforske og rekonstruere en fortelling.

I analysen av brukerveiledningen skrev jeg at den overlappende funksjonaliteten i spillelementene Chalkboard og NPC, dannet grunnlag for dannelsen av to mulige subjektsposisjoner for lærere: En tradisjonell lærer kan bruke Chalkboard og formidle stoff i noe som kan minne om en tradisjonell skole, mens en mer spill-fokusert lærer kan velge å bruke NPCer til liknende oppgaver. Spillutvikleren tilbyr imidlertid enda en subjektsposisjon, en som må sies å være transformativ: I nettressursen https://education.minecraft.net/ inviteres lærere til å diskutere, dele og bruke egne og andres undervisningsopplegg. Gjennom dette delingsfellesskapet har utvikleren 


\section{H. Sandberg}

lagt grunnlaget for et affinity space (Gee, 2006), hvor lærere er frie til i fellesskap å videreutvikle pedagogikken og lærerrollen i bruk av spillet. Tatt i betraktning hvor forskjellige de tre undervisningsoppleggene er, og variasjonen i hvordan og hvor mye av spillutviklerens funksjonalitet som er brukt, er det grunn til å se på lærerens mulige subjektsposisjoner som svært åpne. I beste fall kan det bli et spørsmål om «becoming rather than merely being in the world» (Jackson \& Mazzei, 2012, s. 53).

\section{Konklusjon}

Gjennom diskursanalyse og Foucaults maktbegrep har jeg forsøkt å belyse hvordan Minecraft: Education Edition er lagt opp som læringsressurs, og hvordan spillet kan endre seg for den som tar i bruk et av de lærerskapte undervisningsoppleggene som er delt på nettstedet.

Forforståelsen for denne studien var at Minecraft-spilleren mister makt når spillet blir tatt inn i en skolekontekst for å bli brukt der. Ved å ta i bruk Foucaults dynamiske maktforståelse, operasjonalisert gjennom begreper hentet fra Parker og Fairclough, har jeg vist at mens dette ser ut til å stemme i en spilldiskurs, er det ikke sikkert at det er i den diskursen Minecraft: Education Edition hører hjemme. Et underholdningsspill brukt i skolen, er en interdiskursiv tekst, og lærerne som vil ta Minecraft inn i skolen, og alle de elever som elsker at lærerne gjør det, er kanskje heller del av en skolediskurs, der skole ofte blir sett på som ensformig, teoretisk og obligatorisk. For en skoleelev kan Minecraft: Education Edition være et lekent, kreativt, taktilt og svært velkomment avbrekk i en ellers litt traurig skoledag.

Når det gjelder lærerens mulige subjektsposisjoner, demonstrerer lærerne som har laget undervisningsopplegg, ulike måter å forholde seg til elevene på. Fra VA som eksplisitt gir læreren råd om å holde seg i bakgrunnen og la elevene finne ut av mysteriet selv, til CFTHB som konsekvent beskriver opplegget i en «vi»-form som inkluderer både elevene og læreren selv. Brukerveiledningen fra spillutvikleren tilbyr læreren en ganske tradisjonell subjektsposisjon. Den beskriver verktøy som dels har navn etter tradisjonelle formidlingspedagogiske hjelpemidler, og som vektlegger lærerens muligheter til å kontrollere og formidle. Den tilbyr også en overvåkings teknologi som gjør at læreren ikke trenger å være tilstede selv i spillverdenen for å holde kontroll på elevene der. Her har det imidlertid skjedd mye i overgangen fra tradisjonelle beskrivelser til innovative læreres bruk. En eventuell skepsis til Minecraft: Education Edition som en trussel for frie kreative læreringsprosesser, synes å være ubegrunnet, både på grunn av hvordan læringsoppleggene varierer $\mathrm{i}$ hvordan spillelementene er tatt i bruk, og hvordan en slik kreativ frihet ser ut til å være ivaretatt $\mathrm{i}$ at brukermassen er organisert $\mathrm{i}$ et faglig-sosialt nettverk der lærere deler sine opplegg og erfaringer.

Det jeg ikke har kunnet se i denne analysen, er hvordan lærere i klasserommet faktisk legger opp undervisning med de tre læringsoppleggene og spillet inkludert de fem spillelementene, og hvordan elevene $\mathrm{i}$ sin tur forholder seg til spillet og 
undervisningen, slik det til slutt framstår for dem. Jeg har vist at spillelementene i Minecraft: Education Edition gir læreren verktøy for omfattende overvåkning og kontroll, men undervisningsoppleggene som er laget av lærere tyder på at det ikke slike behov som motiverer dem til å bruke Minecraft i undervisningen.

\section{Forfatterbiografi}

Magnus Henrik Sandberg er stipendiat ved Institutt for lærerutdanning, NTNU Norges teknisknaturvitenskapelige universitet. Han har tidligere vært universitetslektor i prosjektet Smart læring hvor han jobbet med digital kompetansebygging i skolen og høyre utdanning. Før det var han lektor i videregående skole, hvor han la vekt på å jobbe innovativt og utforskende med dataspill og andre digitale medier i undervisningen. Sandberg har tidligere utviklet hjelperessurser for spillbasert læring for Medietilsynet og Senter for IKT i opplæringen, og har skrevet læreverk i samfunnsfag for barne- og ungdomstrinnet.

\section{Referanser}

Borregaard, K. (2016). Fraction stories. Hentet fra https://education.minecraft.net/lessons/fraction-stories/

Bos, B., Wilder, L., Cook, M., \& O’Donnell, R. (2014). Learning Mathematics through Minecraft. Teaching Children Mathematics, 21(1), 56-59.

Davis, K., Boss, J. A., \& Meas, P. (2018). Playing in the virtual sandbox: Students' collaborative practices in minecraft. International fournal of Game-Based Learning, 8(3), 56-76. DOI: http://dx.doi.org/10.4018/ IJGBL.2018070104

de Sousa, F., Rasmussen, I., \& Pierroux, P. (2018). Zombies and ethical theories: Exploring transformational play as a framework for teaching with videogames. Learning, Culture and Social Interaction, (19) (December 2018), 40-50. DOI:https://doi.org/10.1016/j.lcsi.2018.04.011.

Dodgson, D. (2017). Digging deeper: Learning and re-learning with student and teacher minecraft communities. Tesl-ej, 20(4), 1-12.

Egenfeldt-Nielsen, S., Smith, J. H., \& Tosca, S. P. (2008). Understanding video games: The essential introduction. New York: Routledge.

Eliassen, K. O. (2016). Foucaults begreper. Oslo: Spartacus.

Ellison, T. L., \& Evans, J. N. (2016). «Minecraft,» teachers, parents, and learning: What they need to know and understand. School Community fournal, 26(2), 25-43.

Fairclough, N. (1993). Critical Discourse Analysis and the Marketization of Public Discourse:The Universities. Discourse E Society, 4(2), 133-168. DOI: https://doi.org/10.1177/0957926593004002002

Foucault, M. (1977). Discipline and punish: the birth of the prison. New York: Pantheon Books,

Gee, J. P. (2006). Situated language and learning: a critique of traditional schooling. New York: Routledge.

Hontvedt, M., Sandberg, M. H., \& Silseth, K. (2013). På spill for læring: om dataspill som læringsressurs i skolen. I S.V. Knudsen (Red.), Pedagogiske tekster og ressurser i praksis (s. 199-221). Oslo: Cappelen Damm Akademisk.

Jackson, A. Y., \& Mazzei, L. A. (2012). Thinking with theory in qualitative research: viewing data across multiple perspectives. Abingdon and New York: Routledge.

Johnson, S. (2012). Theme is not meaning: Who decides what a game is about? I C. Steinkuehler, K. Squire, \& S. A. Barab (Red.), Games, learning, and society: learning and meaning in the digital age (s. 32-40). Cambridge: Cambridge University Press.

Klevjer, R. (2006). What is the Avatar? Fiction and Embodiment in Avatar-Based Singleplayer Computer Games. (Doktorgradsavhandling). Bergen: Universitetet i Bergen. Hentet fra https://folk.uib.no/smkrk/docs/ RuneKlevjer_What\%20is\%20the\%20Avatar_finalprint.pdf

Kuhn, J., \& Stevens, V. (2017). Participatory culture as professional development: Preparing teachers to use «minecraft» in the classroom. TESOL fournal, 8(4), 753-767.

Latour, B. (1991). Technology is society made durable. I J. Law (Red.), A sociology of monsters: essays on power, technology, and domination (s. 103-132). London og New York: Routledge.

McColgan, M. W., Colesante, R. J., \& Andrade, A. G. (2018). Pre-service teachers learn to teach with serious games. Fournal of STEM Education: Innovations and Research, 19(2), 19-25. 


\section{H. Sandberg}

Medietilsynet (udatert). Minecraft - et undervisningsopplegg. Hentet fra http://www.medietilsynet.no/ globalassets/publikasjoner/minecraft_undervisningsopplegg_web.pdf

Minecraft: Education Edition. (2017a). Minecraft Edu. Hentet fra https:/education.minecraft.net/support/ knowledge-base/minecraftedu/

Minecraft: Education Edition. (2017b). Features of Minecraft: Education Edition. Hentet fra https://education. minecraft.net/support/knowledge-base/features/

Minecraft: Education Edition. (2017c). Specialty Blocks (Allow, Deny, Border, Structure). Hentet fra https:// education.minecraft.net/support/knowledge-base/specialty-blocks/

Minecraft Wiki (2018, 17.juli). Classic. Hentet fra https://minecraft.gamepedia.com/Classic

Nebel, S., Schneider, S., \& Rey, G.D. (2016). Mining Learning and Crafting Scientific Experiments: A Literature Review on the use of Minecraft in Education and Research. Educational Technology E Society, 19(2), 355-366.

Parker, I. (1992). Discourse Dynamics: Critical Analysis for Social and Individual Psychology. London: Routledge.

Parker, I. (1994). Reflexive research and the grounding of analysis: social psychology and the psy-complex, Fournal of Community and Applied Social Psychology, 4(4), 239-52.

Silseth, K. (2012). The multivoicedness of game play: Exploring the unfolding of a student's learning trajectory in a gaming context at school. International fournal of Computer-Supported Collaborative Learning, 7(1), 63-84.

Spieldenner, B., \& Baddeley, S. (2018). Verona adventure. Hentet fra: https://education.minecraft.net/lessons/ verona-adventure/

Squire, K., \& Barab, S. (2004). Replaying history: Engaging urban underserved students in learning world history through computer simulation games. Paper presented at the 6th International Conference on Learning Sciences, Santa Monica, CA, United States. Hentet fra https://dl.acm.org/citation.cfm?id=1149188

Telfer, L. (2016a). Create Fred the human body. Hentet 20. mai 2018 fra https://education.minecraft.net/lessons/ create-fred-the-human-body/

Telfer, L. (2016b). Using Microsoft Education Edition for 21st-Century Skills - A lesson walkthrough [videoklipp]. Hentet fra https://www.youtube.com/watch?v=PstKHf85k3s\&feature=youtu.be

Wooffitt, R. (2005). Conversation analysis and discourse analysis. London: SAGE Publications, Doi: https:// dx.doi.org/10.4135/9781849208765 